\title{
ФОРМУВАННЯ ПРОФЕСІЙНОЇ САМОСВІДОМОСТІ МАЙБУТНІХ УЧИТЕЛІВ У ПРОЦЕСІ ФАХОВОЇ ПІДГОТОВКИ У ВНЗ І-ІІ РІВНЯ АКРЕДИТАЦЇ̈
}

Колбакова Т. С. Формування професійної самосвідомості майбутніх учителів у процесі фахової підготовки у ВНЗ І-ІІ рівня акредитації.

У статті розглянутј питання формування професійної самосвідомості майбутніх учителів у процесі фахової підготовки у ВНЗ І-ІІ рівня акредитації. Визначено поняття професійної самосвідомості, її складників, розкрито особливості професійно важливих характеристик професійної самосвідомості майбутніх учителів.

Ключові слова: професійна самосвідомість, професійне самовизначення, самореалізація, рефлексія.

Колбакова Т. С. Формирование профессионального самосознания будущих учителей в процессе профессиональной подготовки в ВУЗЕ I-II уровня аккредитации.

В статье рассмотрены вопросы формирования профессионального самосознания будущих учителей в процессе профессиональной подготовки в ВУЗе I-II уровня аккредитации. Определено понятие профессионального самосознания, его составляющих, раскрыты особенности профессионально важных характеристик профессионального самосознания будущих учителей.

Ключевые слова: профессиональное самосознание, профессиональное самоопределение, самореализация, рефлексия.

Kolbakova T.S. Forming of professional consciousness of future teachers in the process of professional training at higher schools of the first ${ }^{t}$ and the second accreditation levels.

The article discusses issues concerning developing professional consciousness of future teachers in the process of their professional training at universities of the first and the second accreditation levels. The author describes the idea of professional consciousness and its components. She also defines features of professionally important characteristics of professional consciousness of future teachers.

Key words: professional consciousness, professional self-determination, selfrealization, reflection.

Суспільно-економічне реформування суспільства передбачає підвищення рівня самосвідомості, зокрема й у професійній діяльності, як головному напрямку становлення людської особистості. На сучасному етапі до людини як до суб'єкта професійної діяльності висуваються більш суворі вимоги. Тому велика увага приділяється формуванню професійної самосвідомості, походження та розвиток якої нерозривно пов'язані 3 рівнем професійної підготовки. Адже професійна самосвідомість становить складне особистісне утворення, яке формується під впливом професійного середовища й активної участі суб'єкта у професійній діяльності, $є$ невід'ємним складником професійної свідомості і відтворює певний рівень ії зрілості.

Результати досліджень та досвід роботи вищої школи підтверджують, що фундаментальну основу становлення особистості майбутнього вчителя складає його професійна самосвідомість. Теоретичною основою роботи стали дослідження як 
вітчизняних авторів - С. Батракової, І. Вачкова, О. Гури, А. Деркача, А. Маркової, М. Мащенко, О. Москаленко, В. Толочека, Л. Шнейдер, Н. Чепелєвої.

У цих працях розглядаються такі питання: структура самосвідомості, динаміка ії розвитку, соціально-перцептивні аспекти самосвідомості, пов'язані з особливостями формування самооцінки, із самоусвідомленням власної особистості.

Водночас у загальному огляді наукових джерел про професійне навчання майбутнього педагога не виявлено праць, присвячених формуванню професійної самосвідомості майбутніх учителів. Вивчення публікацій 3 проблеми формування професійної самосвідомості майбутніх учителів, спостереження, аналіз, результати анкетування i проведення досліджень дозволяють стверджувати, що одним із найбільш суттєвих недоліків у підготовці майбутнього вчителя є несформованість професійної самосвідомості. Студенти випускних курсів, молоді вчителі, маючи глибокі теоретичні знання, не вміють використати їх на практиці, відчуваючи тривожність і невпевненість у власних силах [3].

Mema cmammi- теоретично обгрунтувати i визначити зміст формування професійної самосвідомості майбутніх учителів у процесі фахової підготовки.

Завдання дослідження:

- на основі теоретичного аналізу літератури визначити зміст, складники професійної самосвідомості майбутніх учителів;

- дослідити стан формування професійної самосвідомості майбутніх учителів у процесі фахової підготовки;

- охарактеризувати навчальний заклад як об'єкт і базу дослідження;

- розробити тренінгову програму «Формування професійної самосвідомості майбутніх учителів у процесі навчання у ВНЗ I -II рівня акредитації».

Об’єкт дослідження - професійна самосвідомість майбутніх учителів у процесі фахової підготовки у ВНЗ I -ІІ рівня акредитації.

Предмет дослідження - зміст, форми і методи формування професійної самосвідомості майбутніх учителів у процесі фахової підготовки.

Розвиток професійної самосвідомості студентів $є$ одним із важливих шляхів підвищення ефективності професійної підготовки майбутніх учителів, оскільки формування цього особистісно-професійного феномену відкриває широкі перспективи для становлення особистості як суб'єкта професійного зростання, здатного успішно регулювати свою поведінку і діяльність в обраній трудовій галузі, а також відчувати відповідальність за ііі результати [1].

У нашому дослідженні самосвідомість розглядається як усвідомлення себе, свого «Я», як суб'єкта діяльності. У структурі самосвідомості, за І. Чесноковою, знаходяться три взаємодіючих компоненти - це самопізнання, самоставлення i саморегуляція [5]. До видів самосвідомості можна віднести: усвідомлення близької і далекої мети, мотивів свого «Я» («Я як діючий суб'єкт»), усвідомлення своїх реальних і бажаних якостей («Реальне Я» і «Ідеальне Я»), пізнавальні уявлення про себе («Я як спостерігає мій об’єкт»), емоційне, чуттєве уявлення про себе, а також професійна самосвідомість особистості.

Найважливішою умовою, яка дозволяє людині стати суб'єктом саморозвитку, є досягнення певного рівня особистісної і професійної самосвідомості. Усвідомлення людиною себе як суб'єкта професійної діяльності відіграє значну роль у регулюванні як професійної праці, так і професійного розвитку суб' єкта загалом [4].

У статті подаємо окремий фрагмент експериментального дослідження i спробуємо в першому наближенні оцінити рівень сформованості професійної самосвідомості майбутніх учителів у процесі фахової підготовки. 
Задля досягнення поставленої мети використовувався комплекс взаємодоповнювальних методів i методик дослідження. До складу психодіагностувального апарату дослідження увійшли: методика самоставлення с. Пантілєєва, В. Століна, методика «Хто я?» (М. Кун, Т. Макпартленд, модифікація Т. Румянцевої), методика діагностування рівня суб'єктивного контролю Дж. Роттера (адаптація С. Бажина, С. Голинкіної, А. Еткинда).

Емпіричні дані дослідження було отримано на базі Нікопольського педагогічного училища ДВНЗ «Криворізький національний університет». Контингент досліджуваних склали дві вікові групи (студенти перших курсів та студенти четвертих курсів (90 осіб). Завдання дослідження полягало в тому, щоб вивчити особливості професійної самосвідомості майбутніх учителів у процесі їх навчання у ВН3, простежити закономірності формування в залежності від професійних установок на педагогічну діяльність, рівня самопізнання самооцінки професійно значущих якостей, саморегуляції під час розв'язання конкретних педагогічних задач, визначення рівня сформованості відповідно мотивів професійного самовдосконалення.

Одним із методів отримання інформації була бесіда. У результаті проведеної бесіди було з'ясовано, що майже половина студентів першого курсу на питання «Назвіть спеціальність Вашої майбутньої професії 3 урахуванням спеціалізації. Укажіть, що для Вас $є$ першочерговим, отримання професії «Вчитель початкових класів» чи спеціалізація?», за результатами опитування повністю і правильно назвали свою спеціальність зі спеціалізацією лише $53 \%$ студентів, для $27 \%$ важливим є отримання професії вчителя початкових класів, для $35 \%$ - спеціалізації «Учитель інформатики у початкових класах», для $29 \%$ - спеціалізації «Вчитель англійської мови в початкових класах», і лише для 9 \% студентів I курсу немає ніякого значення майбутня професія і спеціалізація. На запитання «Чи знаєте Ви, які вимоги висуває вказана професія до людини?» лише 53 \% студентів I курсу можуть назвати необхідні знання, уміння, навички, 17 \% необхідні спеціальні якості особистості. Що стосується загальних якостей особистості, то студенти I курсу вважають їх абсолютно не потрібними. Студенти IV курсу вже можуть назвати необхідні для майбутнього професіонала знання, вміння та навички. На запитання «Причини вашого вступу до педагогічного училища?» були отримані відповіді, за результатами яких можна зробити висновок, що при вступі половина студентів I курсу і IV курсу керувались власними вподобаннями (50 \% та 60 \%), значна частина обрала даний ВНЗ за порадою батьків. Можливість продовжити навчання у ВНЗ приваблює лише $15 \%$ першокурсників та 30 \% студентів IV курсу. На питання «На що Ви орієнтувались під час вибору професії» більшість студентів на перше місце поставили зарплату (50\% студентів I курсу, $25 \%$ студентів IV курсу). Очевидно, що соціальні оцінки значущості для суспільства обраної професії у студентів відсутні, але робота сама по собі цікава для значної кількості студентів. На запитання «Чи плануєте працювати за даною професією?» лише 53 \% студентів відповіли ствердно, серед студентів IV курсу позитивну відповідь дали 89 \%, що може бути показником достатньо високого рівня професійної самосвідомості. Отже, можна говорити про низький рівень знань у студентів I курсу про майбутню професію. Якщо відповіді на питання, пов’язані 3 вибором професії, суттєво не відрізняються у студентів I та IV курсу, то знання про вимоги майбутньої професії у студентів IV курсу значно вищі. У студентів I курсу $є$ лише початкові уявлення про майбутню професію, специфіку майбутньої роботи. Основними якостями майбутнього професіонала вони вважають знання, вміння, навички. На вибір професії вплинула можливість матеріального благополуччя, значну 
частину інформації про світ професії несуть батьки.

Дослідження афективної підструктури самосвідомості проводилося за допомогою методики самоставлення В. Століна, С. Пантілєєва. Проаналізувавши отримані в результаті дослідження дані, можна зробити висновок, що студентам притаманний середній $(50-74)$ та завищений $(74-100)$ рівні виразності складників показників афективної підструктури професійної самосвідомості. Порівнявши показники афективної підструктури професійної самосвідомості досліджуваних вибірок, можна зазначити майже цілковиту тотожність кількісних характеристик студентів 1-го та 4-го курсів, що дає підстави категоризувати їх як такі, які вирізняються позитивним ставленням до себе та впевненістю в досягненні життєвих цілей.

Проте викликає занепокоєння той факт, що показники глобального самоставлення, самоінтересу, самовпевненості, аутосимпатії у студентів 1 -го курсу є дещо завищеними. Такі дані дають підстави говорити про те, що це $є$ свідченням, 3 одного боку, низького рівня самокритичності, слабкого проникнення у власну особистість та недостатньо сформованого раціонального компонента в уявленнях про себе, невміння правильно оцінити результати своєї діяльності, а 3 іншого,- $€$ наслідком дії механізмів «психологічного захисту», який створюють собі першокурсники. Студенти 4-го курсу адекватно порівнюють себе 3 іншими людьми, зіставляють свої якості з внутрішніми еталонами або результатами діяльності інших.

Регуляторна підструктура професійної самосвідомості студентів педагогічного ВНЗ була досліджена за допомогою локусу контролю. Локус контролю становить узагальнене очікування того, якою мірою люди контролюють підкріплення у своєму житті. Із результатів видно, що рівні сформованості регулятивної підструктури студентів 1-го та 4-го курсів дещо відрізняються. Водночас можемо зробити висновок, що в обох групах переважає інтернальний локус контролю, хоча екстернали й інтернали не є «типи», оскільки кожний має характеристики не тільки однієї категорії, але i, незначною мірою, іншої. Отже, більшість студентів, які брали участь у дослідженні, переконані у невипадковості своїх успіхів чи невдач. Вони вважають, що їхні досягнення $є$ результатом компетентності, цілеспрямованості, рівня здібностей і наполегливих зусиль; більшість важливих подій у їхньому житті відбулися в результаті власних дій. Ці дії $\epsilon$ важливим чинником у власному професійному зростанні, організації навчального процесу, міжособистісних стосунках у колективі. Нижчий рівень інтернальності у студентів 4-го курсу можна пояснити зростанням усвідомлення відповідальності за результати праці.

Задля вивчення рівня сформованості когнітивної підструктури професійної самосвідомості було використано методику «Хто я?» (М. Кун, Т. Макпартленд, модифікація Т. Румянцевої). Студентами були написані 20 визначень як відповідь на запитання «Хто Я?», не всі опитувані змогли виконати завдання. У значної кількості першокурсників (10\%) виникла проблема із самоусвідомленням. Якщо рівні сформованості афективного та регулятивного складника в першокурсників дещо вищий, то рівень самоусвідомлення значно нижчий, що є свідченням невпевненості, складності в самоконтролі. Найбільшу частину (58\%-1 курс, 61,9\%- 4 курс) становлять особистісні характеристики. На другому місці у студентів 4-го курсу - характеристики, пов'язані 3 майбутньою професією, а у першокурсників досліджувані характеристики перебувають на останньому місці. Це дає підстави стверджувати, що професійне самоусвідомлення ще не є актуальним для студентів 1-го курсу. Лише половина усвідомлює себе майбутнім професіоналом. Вони більше уваги приділяють статевим характеристикам. Серед студентів 4-го курсу уже $93 \%$ 
усвідомлюють себе майбутніми професіоналами.

Отже, більшість студентів 1-го курсу не мають чіткого самоусвідомлення, мети, професійної спрямованості. Професійна самосвідомість перебуває на середньому рівні. Подібна ситуація спостерігається і в групах 4-го курсу. Але у четвертокурсників підвищується відповідальність за свій вибір, вони усвідомлюють себе майбутніми професіоналами.

Підготовка студентів вищого закладу освіти до педагогічної діяльності повинна передбачати професійне становлення особистості, основою якого $є$ професійна самосвідомість, що охоплює такі основні складники: психологічна готовність до педагогічної діяльності, потреба в самопізнанні, самооцінка професійно значущих якостей, здатність до саморегуляції поведінки в конкретних педагогічних ситуаціях, наявність мотивів професійного самовдосконалення.

Вирішальну роль у формуванні професійної самосвідомості студентів вищого навчального закладу освіти відіграють активні методи навчання (дискусійні, ігрові, моделювання та аналіз педагогічних ситуацій, мікровикладання, тренінгові заняття тощо), які сприяють активізації процесу самопізнання, кращому усвідомленню студентами власних особистісних якостей та їх відповідності обраній професії, розвитку рефлексивних умінь майбутнього педагога.

Водночас наша робота не вичерпує всіх аспектів формування професійної самосвідомості майбутніх учителів. Подальшого дослідження потребує проблема поведінки студентів під час проходження педагогічної практики; управління процесом формування професійної самосвідомості викладачем вищого навчального закладу.

\section{Література}

1. Гура О. I. Психолого-педагогічна компетентність викладача вищого навчального закладу: теоретико-методологічний аспект : [монографія] / О. І. Гура. Запоріжжя : ГУ «ЗІДМУ», 2006. - 332 с. 2. Іванова Т. О. Я - концепція як складова професійної свідомості психологів / Т. О. Іванова // Соціальна психологія. - 2005. $\begin{array}{llll}\text { № } 6 & \text { (14). - } & \text { С. 48-54. } & \text { 3. Климов Е. А. Психология профессионального }\end{array}$ самоопределения / Е. А. Климов. - Ростов-н-Д.: Феникс, 1996. - 495 с. 4. Сухобская Г. С. Развитие самосознания студентов педагогических вузов : автореф. дис. на соискание ученой ступени канд. пед. наук : спец. 13.00.01 / Г. С. Сухобская. М., 1987. - 23 с. 5. Чеснокова И. И. Самосознание личности / И. И. Чеснокова. - М. : Наука, 1974. - 209-225 c.

УДК 37(09)(477)

Марина Радченко

\section{ФЕНОМЕН ПЕДАГОГІЧНОЇ ТВОРЧОСТІ У ВІТЧИЗНЯНІЙ НАУКОВІЙ ДУМЦІ}

Радченко М. В. Феномен педагогічної творчості у вітчизняній науковій думці.

Стаття присвячена огляду джерельної бази з проблеми педагогічної творчості, характеристиці феномену у його історичній ретроспекції, аналізу поглядів вітчизняних науковців-педагогів на запропоновану проблему дослідження та їхнього внеску у становлення педагогіки творчості як науки.

Ключові слова: творча педагогічна діяльність, майбутній учитель, українська педагогічна думка, педагогічна творчість, народна школа.

Радченко М. В. Феномен педагогического творчества в отечественной научной 